\title{
Análise das Manifestações Patológicas em Contenções de Terra Armada de Viadutos da Região Metropolitana do Recife - PE.
}

\author{
Analysis of pathogical manifestations in contention of armed land on viaducts of the \\ Metropolitan Region of Recife - PE.
}

\author{
Danilo José da Costa Barbosa 1,2 (iD orcid.org/0000-0002-3951-686X \\ José Afonso Pereira Vitório ${ }^{\mathbf{1 , 2}}$ (iD orcid.org/0000-0003-3981-3300 \\ ${ }^{1}$ Escola Politécnica de Pernambuco, Universidade de Pernambuco, Recife, Brasil, \\ 2 Pós-graduação em Inspeção, Recuperação e Manutenção de Estruturas, Escola Politécnica de Pernambuco, Pernambuco, Brasil. \\ E-mail do autor principal: Danilo José da Costa Barbosa danilojcb@gmail.com
}

\section{Resumo}

Este trabalho tem como objetivo identificar as manifestações patológicas existentes nas obras de contenção de terra armada em quatro viadutos de duas rodovias da Região Metropolitana do Recife, a PE15 e a PE-22. As obras da PE-15, foram construídas para Copa do Mundo de 2014 e já apresentam diversos problemas causados pela falta de manutenção, além dos erros construtivos. A contenção da PE22 foi inaugurada em 2003 e apresenta problemas mais graves do que as contenções da PE-15. Se os problemas identificados durante as inspeções, não forem corrigidos com brevidade, poderão gerar grandes custos em intervenções de recuperação e até em acidentes, caso haja grande demora nas correções. Ao final deste trabalho são feitas conclusões e apresentadas recomendações para melhorar a conservação, 0 desempenho e a vida útil dos muros de terra armada.

Palavras-Chave: Terra Armada; Contenção; Patologia; Recuperação.

\begin{abstract}
This Study aims to identify the pathological manifestations existing on the contention constructions of armed land on four viaducts in two highways of the Metropolitan Region of Recife, the PE-15 and the PE22. The constructions of PE-15, were built to the 2014 World Cup and already present several issues caused by the malfunction, besides constructive errors. The contention of PE-22 was open at 2003 and present more severe issues than the contentions the PE-15. If not adjusted within briefness, the problems identified during the inspections could generate wide costs in recovery interventions and even accidents, in case there is a large delay solving it. At the end of this task conclusions and recommendations are made and presented to improve the conservation, the performance and the armed land's walls lifespan.
\end{abstract}

Key-words: Armed land; Contention; Pathology; Recovery. 


\section{Introdução}

As contenções em terra armada são muros em solos mecanicamente estabilizados, que de acordo com a NBR 19286/2016 [1] são construídos pela associação do solo de aterro com propriedades adequadas, armaduras flexíveis, colocadas, horizontalmente em seu interior, à medida que o aterro vai sendo construído, e por uma pele ou parâmetro flexível externo fixado às armaduras, destinados a limitar o aterro.

Essa técnica de reforço de solos vem se apresentando como uma das alternativas técnico econômicas mais viáveis, devido à grande capacidade de suportar carregamentos e a viabilidade de ser construída com elevadas alturas (da ordem de 20 metros), por isso vem sendo cada vez mais utilizada em diversos tipos de obras de engenharia civil tendo seu uso crescente em obras viárias desenvolvidas no Brasil, inclusive em Pernambuco. Apesar do crescente uso dessa técnica, ela ainda é pouco abordada na literatura especializada.

Assim como os demais sistemas construtivos as contenções em terra armada também apresentam desgastes e manifestações patológicas que contribuem para o comprometimento do desempenho estrutural e para a diminuição da vida útil. O fato de grande parte de tais estruturas estarem implantadas nos aterros de acesso de viadutos localizados em intensos corredores de tráfego em áreas urbanas, faz com que as patologias e danos estruturais exijam atenções especiais no que se refere à prevenção de graves acidentes, que podem ser evitados, caso haja uma adequada manutenção preventiva.

Desta maneira, foi realizado um estudo para identificar as manifestações patológicas e os danos estruturais nas contenções de terra armada dos aterros de acesso de quatro viadutos de duas rodovias estaduais da Região Metropolitana do Recife, a PE-15 e a PE-22. As observações feitas durante as inspeções permitiram diagnosticar os problemas existentes e recomendar a realização de ações voltadas para a garantia das adequadas condições de funcionalidade, segurança e durabilidade desses tipos de obras.

\section{Metodologia}

Foi adotada uma pesquisa qualitativa, de natureza aplicada, respaldada pelos conceitos que constam da literatura existente sobre o tema estudado, conforme pesquisa bibliográfica.

Trata-se de um estudo de caso realizado em contenções de terra armada de quatro viadutos da Região Metropolitana do Recife, escolhidas por fazerem parte de duas rodovias que funcionam como importantes elementos de ligação entre a cidade do Recife e outras cidades da Região Norte, como Olinda, Paulista e Igarassu. Também contribuiu para a definição da amostra, o fato de as contenções da rodovia PE-15 terem sido construídas em 2014, como parte da infraestrutura para a copa do mundo ocorrida no Brasil naquele ano, e a contenção da PE22 ter sido construída em 2003. Essa diferença de onze anos entre as duas obras também forneceu informações importantes quanto à intensidade das manifestações patológicas identificadas.

O levantamento dos danos e das patologias nas obras de contenção foi feito por meio de inspeções visuais e registros fotográficos, com duração de quatro dias. O levantamento geométrico das dimensões das estruturas foi realizado através de medições in loco das alturas e das extensões das contenções, com o auxílio de trena lazer. As demais informações foram obtidas por meio do Google Earth. Posteriormente foi feita a identificação das possíveis causas das avarias e elaborado um diagnóstico visando as possíveis correções dos problemas.

\section{Revisão bibliográfica}

O reforço de solos não é uma ideia nova. As construções do Império Inca e a Muralha da China são alguns exemplos disso.

A técnica construtiva denominada Terra Armada foi desenvolvida no Laboiratoire Central dês Ponts et Chaussées, localizado em Paris, no ano de 1967 pelo engenheiro e arquiteto Henri Vidal. Inicialmente Henri Vidal propôs o uso de polímeros reforçados com fibras de vidro; mais tarde, passou a utilizar reforços de aço maciço e de alumínio, visto que a primeira solução não foi bem-sucedida. Depois de 
diversas experiências começou a ser utilizado o material polímero [2].

Atualmente, essa técnica tem sido utilizada para a execução de muros de arrimo e encontros de viadutos, especialmente em obras urbanas, onde os espaços são reduzidos para a construção de taludes dos aterros e a necessidade de um bom aspecto para as rampas de acesso limitam o emprego de outras soluções convencionais [3].

\subsection{Tipos de Contenções utilizadas em aterros de pontes e viadutos}

Usualmente são adotados os seguintes tipos de contenções para aterros de acesso de pontes e viadutos:

- $\quad$ Muros de arrimo (concreto armado, concreto ciclópico, alvenaria de pedras, etc.);

- Gabiões (tipo manta, caixa, colchão Reno, saco, etc.);

- Taludes Revestidos (com redes de alta resistência, vegetação, etc.);

- Terra armada (objeto deste estudo).

- Também existem situações nas quais, por questões de ordem funcionais ou estéticas, é feita a opção de prolongar a estrutura nas duas extremidades dos viadutos, evitando assim as contenções. Essa alternativa precisa ser analisada sob o ponto de vista da viabilidade técnica e econômica.

\subsection{Sistemas de Terra Armada mais utilizados}

Existem diversos sistemas de execução para terra armada. O Sistema mais utilizado, consiste em executar os painéis com solo reforçado em apenas uma extremidade; no caso dos sistemas de paramento duplo, o elemento de pele (escamas) ocupa as duas extremidades laterais e as armaduras podem ser continuas, sobrepostas ou separadas pelo aterro, como pode ser visto na Figura 1.

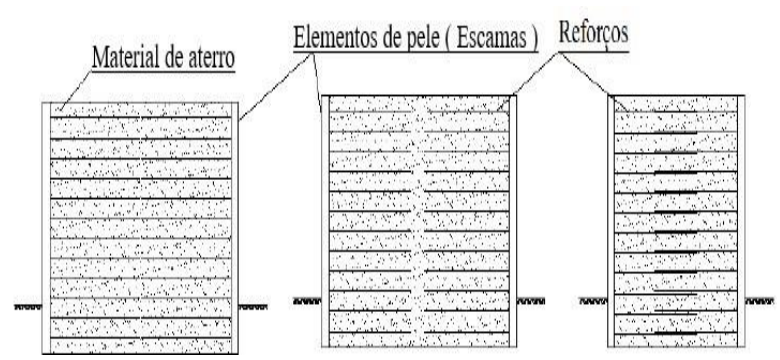

Figura 1: Esquema de um sistema de terra armada. Fonte: LCPC-SETRA (1979) apud Silva (2012).

\subsubsection{Fundação}

A fundação mais utilizada nesse sistema, dependendo das características do solo é a fundação direta, chamada de soleira. Ela deve ser apoiada em um solo resistente e com alto grau de compactação e é composta geralmente por uma base retangular de concreto ao longo de todo o muro. Também existem situações nas quais a baixa capacidade de suporte do solo, como é o caso das argilas moles, impõem a necessidade da utilização de fundações profundas (estacas). Porém cada caso deve ser analisado isoladamente para definir qual a fundação mais apropriada, dos pontos de vista estrutural e econômico.

\subsubsection{Aterro}

De acordo com Maparagem, o material utilizado no aterro precisa ter boa durabilidade, boa interação solo-reforço e deve ser previsto projeto de drenagem para manter a estabilidade da estrutura e diminuir as pressões neutras. O sistema também requer uma boa resistência interna do solo. Outra questão de fundamental importância é a obtenção de um rigoroso grau de compactação do maciço no interior da contenção em terra armada para garantir a aderência das armaduras (tiras de aço) com o solo, condição fundamental para a estabilidade do maciço [4].

A depender do tipo do elemento de reforço utilizam-se materiais de aterro do solo específicos, de acordo com os procedimentos adotados nos aterros de obras rodoviárias. 


\subsubsection{Painéis pré-moldados}

Existem alguns formatos de placas pré-fabricadas de concreto, também chamadas de escamas, que podem ser hexagonais, retangulares ou de outra forma geométrica. A Figura 2 mostra um exemplo de placa utilizada.

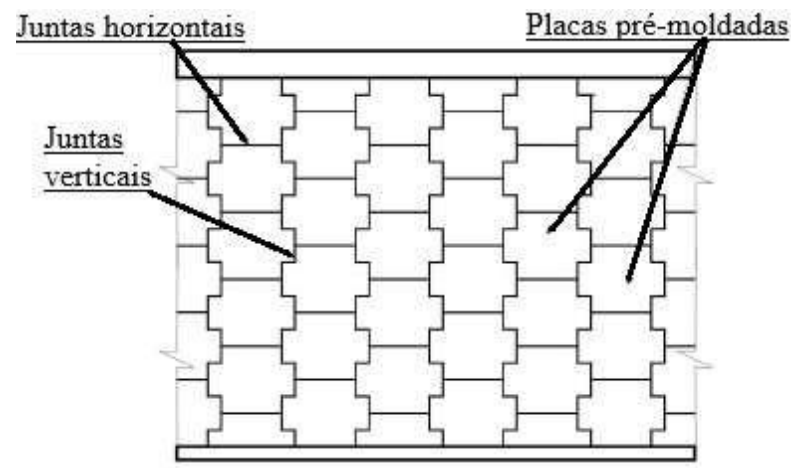

Figura 2: Detalhe de um tipo de placa pré-moldada usada em aterros de terra armada.

Fonte: Vitorio (2002).

Nos painéis, são colocados dois pontos para suspensão do material que será içado em obra, além de pontos para ligação da placa com a armadura de tração, como pode ser visto na Figura 3.

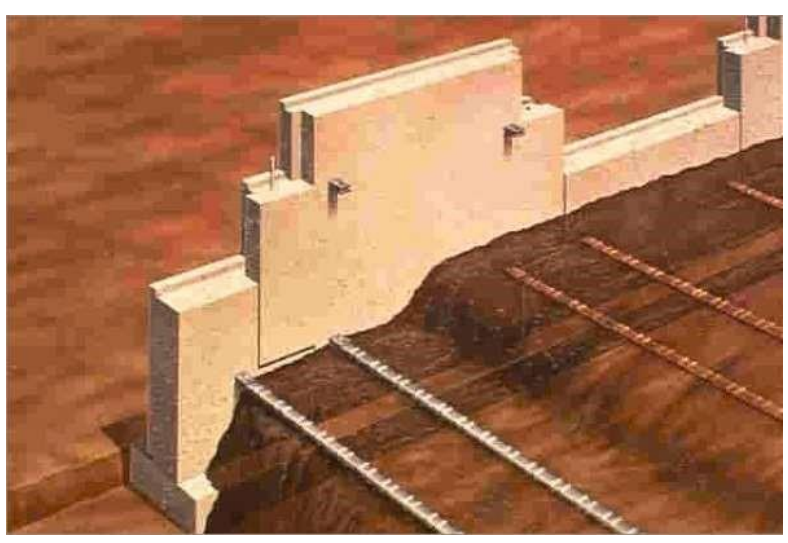

Figura 3: Vista do maciço da terra armada, do posicionamento das armaduras e suas ligações com as escamas.

Fonte: www.terraarmada.com.br.

De acordo com Fontana e Santos, precisa-se ter um cuidado redobrado com as tensões que atuam na estrutura de contenção, provenientes do peso próprio do maciço e da sobrecarga. Essas tensões geram um empuxo ativo que pressiona o maciço de solo contra as placas do paramento [5].
Com isso, a deformação nas primeiras camadas aumenta de acordo com a elevação da altura do muro de terra armada, como na Figura 4.

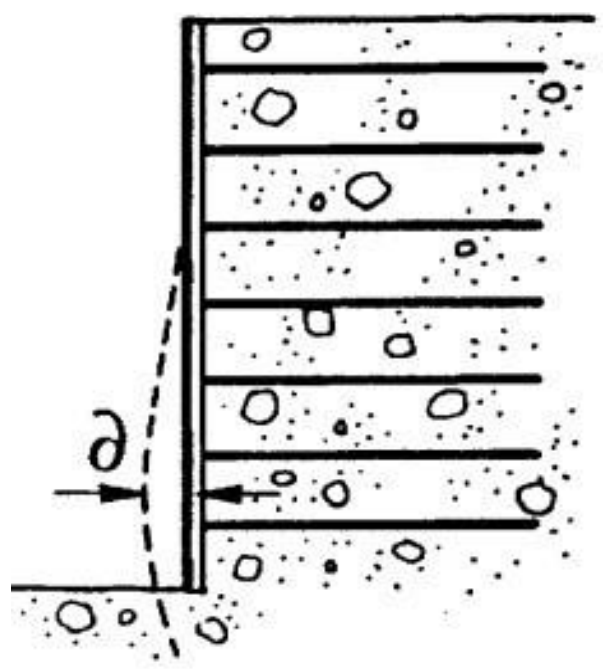

Figura 4: Deslocamento horizontal do muro de terra armada.

Fonte: Schlosser apud Springer [6].

\subsubsection{Elementos de reforço}

Os elementos de reforço em termos da deformabilidade podem ser considerados inextensíveis (pouco deformáveis) ou extensíveis (deformáveis), sendo os inextensíveis os de tipos metálicos e os extensíveis dos tipos poliméricos [2].

A armação tem a função de combater os esforços de tração do sistema, visto que o solo tem pouca resistência à tração.

\subsection{Vantagens e Desvantagens}

A grande vantagem da aplicação da Terra Armada em obras de contenção é a baixa complexidade dos processos construtivos, além de:

- Rapidez de execução da montagem das peças pré-moldadas e da fixação das armaduras [7];

- Fundações diretas e mais baratas;

- Não requer mão-de-obra especializada;

- Muros com capacidade de atingir grandes alturas (da ordem de 20,00 m) [7]; 
- Solução adequada para viadutos em áreas urbanas, onde os espaços são reduzidos e não permitem taludes nas cabeceiras, nem obras de contenção convencional [7];

- $\quad$ Custos reduzidos, quando comparadas com outros tipos de contenções;

- Facilidade quanto à grande flexibilidade, variação das formas e alturas dos parâmetros verticais [7];

- Apresenta um bom aspecto para as rampas de acesso [7].

Para demonstrar as vantagens no uso da Terra armada e seu menor custo de execução, Pessoa analisou e comparou o custo construtivo de três sistemas de contenção: muro de gravidade, terra armada e solo reforçado por geossintético [8], cujos resultados são apresentados na Figura 5.

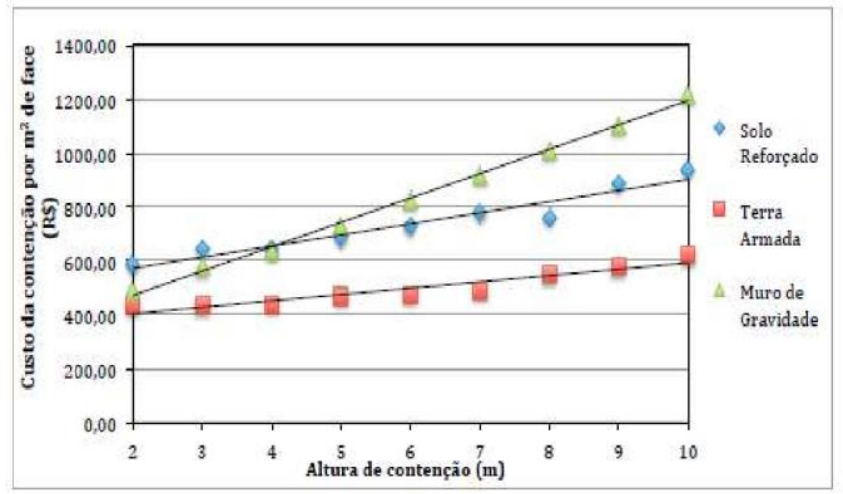

Figura 5: Comparação entre custos de tipos de contenções.

Fonte: PESSOA (2016).

O gráfico mostra, claramente, que a solução de terra armada é a que apresenta o menor custo entre todas as soluções analisadas e quanto maior a altura do muro, menor o custo por $\mathrm{m}^{2}$ desta contenção.

É importante observar que dependendo das extensões das rampas do aterro a ser arrimado, do tipo do solo local e outras condicionantes, as estruturas de contenção em concreto armado podem ser a soluções técnico-econômicas mais viáveis.

Existem também desvantagens nesse sistema de contenção como:

- Necessidade de solos granulares
selecionados;

- $\quad$ Requer um rigoroso controle da compactação dos aterros [7];

- Requer um rigoroso plano de manutenção para evitar infiltração de água sob o terrapleno, a deterioração das escamas e a corrosão das armaduras [7];

- As falhas de execução (desaprumo, arestas quebradas, etc.), além de ficarem bastante visíveis, contribuem para o rápido aparecimento de patologias no concreto e nas armaduras [7];

- Dificuldades para recuperação da estrutura.

\subsection{Vida útil e durabilidade}

Deve-se entender que a concepção de uma construção durável implica na adoção de um conjunto de decisões e procedimentos, relacionados às etapas de projeto, execução e manutenção, que garantam à estrutura e aos materiais que a compõem um desempenho satisfatório ao longo da sua vida útil. Este tema é atualmente objeto de muitas pesquisas para as estruturas em geral e especialmente para as pontes e viadutos, de modo que o seu conceito também pode ser aplicado às contenções de terra armadas, com as devidas adequações às especificidades de tais estruturas.

\subsection{Corrosão de armaduras}

Num conceito difundido e aceito universalmente, pode-se definir corrosão como a deterioração de um material, geralmente metálico, por ação química ou eletroquímica do meio ambiente, aliada ou não a esforços mecânicos [9].

A corrosão de armadura traz muitos danos às estruturas, que são evidenciados através de manifestações patológicas como manchas superficiais, expansão, fissuração, destacamento do cobrimento, redução das seções e perda de aderência das armaduras, que podem levar até ao colapso.

\subsection{Fissuras}

Thomaz, afirma que dentre os inúmeros problemas patológicos que afetam as construções, as fissuras são uns dos mais importantes, pelo fato de significar um aviso de um eventual estado de risco, 
por comprometer o desempenho da obra e pelo efeito psicológico negativo que a fissuração exerce sobre os usuários [10].

\subsection{Infiltração, manchas e eflorescências}

Grande parte das manifestações patológicas nas estruturas são decorrentes da infiltração de água. Nas contenções de terra armada esse problema pode causar graves consequências, pois altera as condições de compactação do aterro, provocando deformações e recalques no maciço, diminuem as condições de aderência entre as armaduras e o aterro e também atingem as juntas entre as escamas pré-moldadas, provocando manchas e o surgimento de vegetação. Para evitar tais problemas devem ser previstos dispositivos que permitem aumentar a eficiência da drenagem, escoando a água sem carregamentos de finos, e evitando comprometer a estabilidade da obra [4].

A eflorescência ocorre devido ao depósito de sais na superfície das alvenarias ou de materiais cimentícios, situação comum nas contenções em terra armada, como resultado da lixiviação de compostos hidratados. Pode ser evitada por meio de uma drenagem eficiente.

\subsection{Manutenção}

Manutenção é o conjunto de atividades necessárias para a garantia do desempenho satisfatório de uma obra ao longo do tempo, ou seja, um conjunto de rotinas com a finalidade de prolongar a vida útil da obra a um custo compensador [11].

Toda obra necessita de um plano de manutenção, que consiste em estipular períodos de inspeções periódicas, de modo que as informações dessas inspeções permitam tomar as providencias cabíveis, que podem ser desde um simples serviço de limpeza até uma recuperação ou reforço da estrutura.

As manutenções das contenções de terra armada devem ser realizadas como parte de um procedimento mais amplo, que contemple a manutenção da Obra de Arte Especial na qual está inserida.

\section{Estudo de caso}

Este estudo de caso refere-se à análise das contenções de terra armada de quatro viadutos situados, respectivamente, nas rodovias PE-15 e PE22 na Região Metropolitana de Recife, denominados neste estudo de viadutos $1,2,3$, e 4 conforme as locações mostradas nas Figuras 6 e 7 .

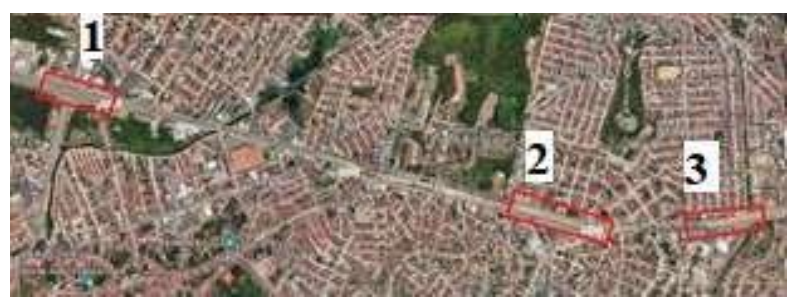

Figura 6: Locação dos viadutos 1, 2 e 3.

Fonte: Google Maps.

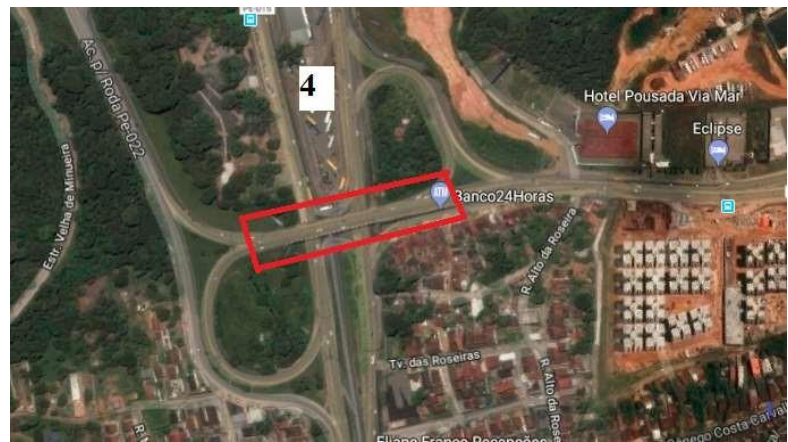

Figura 7: Locação do Viaduto 4. Fonte: Google Maps.

\subsection{Descrição das obras analisadas}

Todos os viadutos têm tabuleiros em vigas prémoldadas protendidas; a mesoestrutura é composta por travessas e pilares em concreto armado e as fundações são em estacas.

As obras 1,2 e 3 fazem parte do corredor NorteSul e foram construídas para melhor mobilidade urbana entre os Municípios de Recife e Igarassu. Essas obras fizeram parte das melhorias de infraestrutura para a Copa do Mundo de 2014.

\subsubsection{Viaduto 1}

É composto por dois viadutos paralelos, localizados nas imediações do Complexo de Salgadinho, Município de Olinda-PE, e foi entregue à população em 2011. 
Cada viaduto tem, aproximadamente, incluindo os aterros de acesso, 570 metros de comprimento e 12 metros de largura. A superestrutura tem extensão de 380 metros e as contenções dos aterros de acesso tem, respectivamente, 90 e 100 metros de comprimento e, aproximadamente, 4 metros de altura. A Figura 8 mostra uma vista geral da contenção.

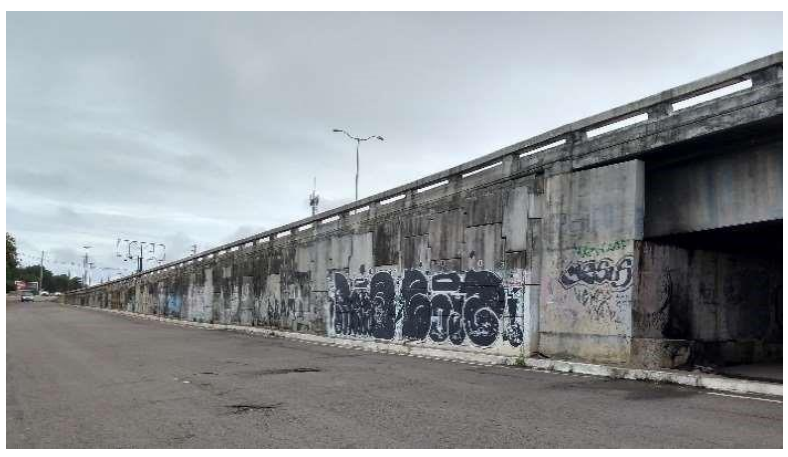

Figura 8: Contenção em Terra Armada do viaduto 1. Fonte: Autor

\subsubsection{Viaduto 2}

O viaduto 2, conhecido como viaduto Bajado, está localizado no Bairro dos Bultrins, em Olinda-PE e sua inauguração aconteceu em fevereiro de 2013.

Também é constituído por duas obras paralelas, cada uma com aproximadamente, 340 metros de extensão e 10 metros de largura, com 2 faixas de tráfego. As dimensões das contenções em Terra Armada, são, de aproximadamente, 50 e 60 metros de comprimento com 3,20 metros de altura, conforme a Figura 9.

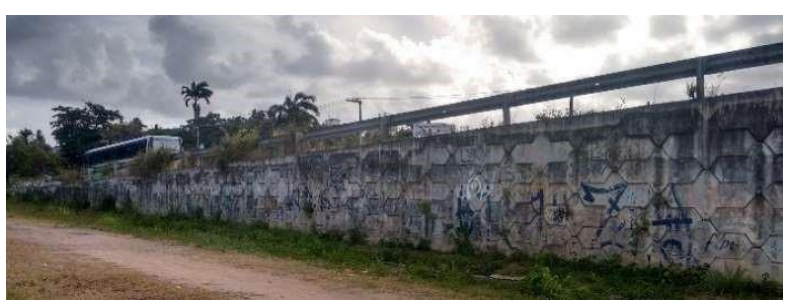

Figura 9: Muro de Terra Armada do viaduto Bajado.

Fonte: Autor

Devido ao relevo da região um dos muros possui, aproximadamente 23 metros de comprimento e 1,50 metro de altura, como pode ser visto na Figura 10.

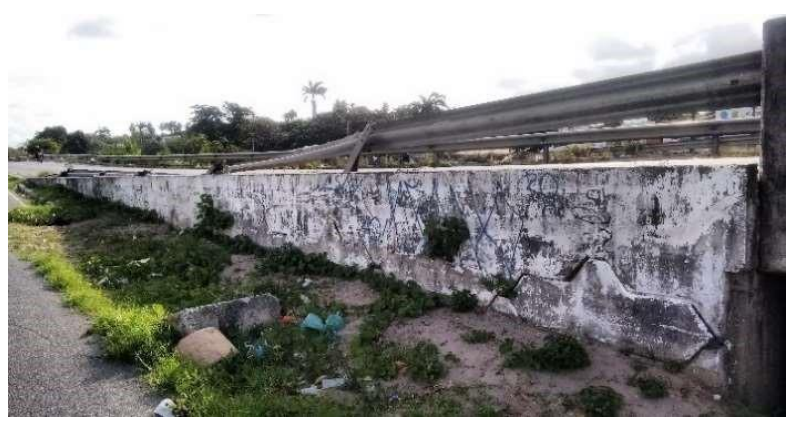

Figura 10: Contenção no viaduto Bajado. Fonte: Autor

\subsubsection{Viaduto 3}

Essa obra consta de um viaduto com 4 faixas ( 2 para tráfego de automóveis e 2 para o BRT) e sua inauguração foi em agosto de 2013. O viaduto, ilustrado na Figura 11, está localizado no Bairro de Ouro Preto, Olinda-PE, e foi batizado com o nome do Senador Nivaldo Rodrigues Machado.

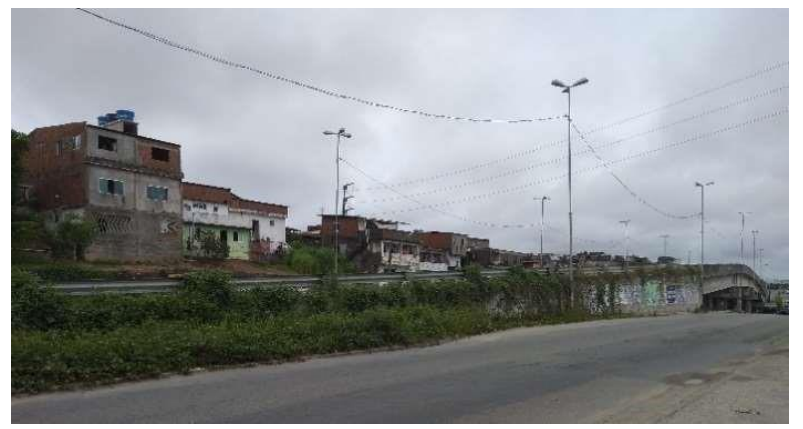

Figura 11: Viaduto de Ouro Preto (Senador Nivaldo Machado).

Fonte: Autor

Ele tem, aproximadamente, 310 metros de extensão e 20 metros de largura. As contenções de terra armada, mostradas na Figura 12, têm, respectivamente, 25 e 70 metros de comprimento com altura máxima em torno de 3,50 metros. 


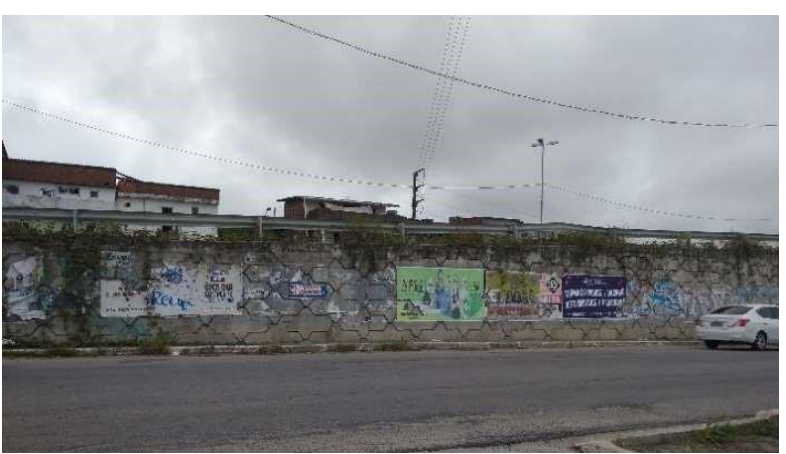

Figura 12: Terra Armada do Viaduto Senador Nival-do Rodrigues Machado.

Fonte: Autor

\subsubsection{Viaduto 4}

Construído entre os anos de 2002 e 2003, o Viaduto leva o nome do Médico Dr. Nilson Falcão e está localizado no entroncamento das rodovias PE 15 com a PE - 22, no Município do Paulista.

O viaduto tem, aproximadamente, 230 metros de comprimento, 20 metros de largura e 6 metros de altura. Na contenção, mostrada na Figura 13, as paredes transversais têm, aproximadamente, 10 metros de comprimento.

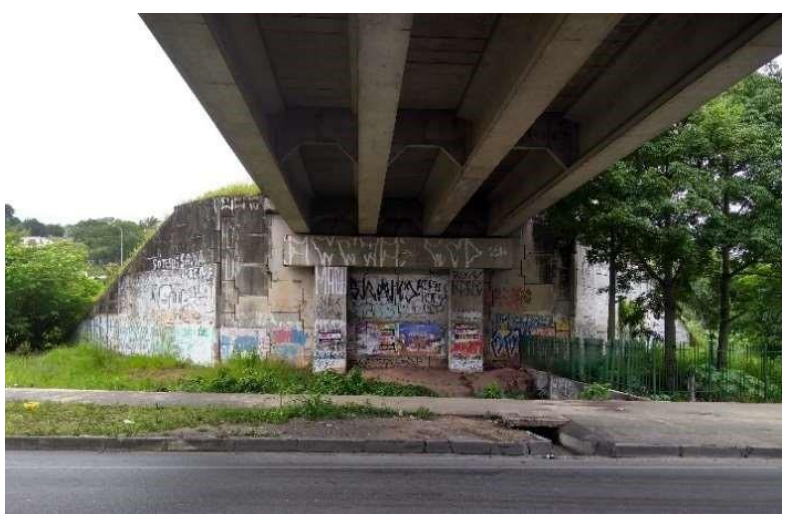

Figura 13: Contenção Oeste do Viaduto Dr. Nilson Falcão. Fonte: Autor

A contenção do lado Leste possui, aproximadamente, 130 metros de comprimento, conforme a Figura 14.

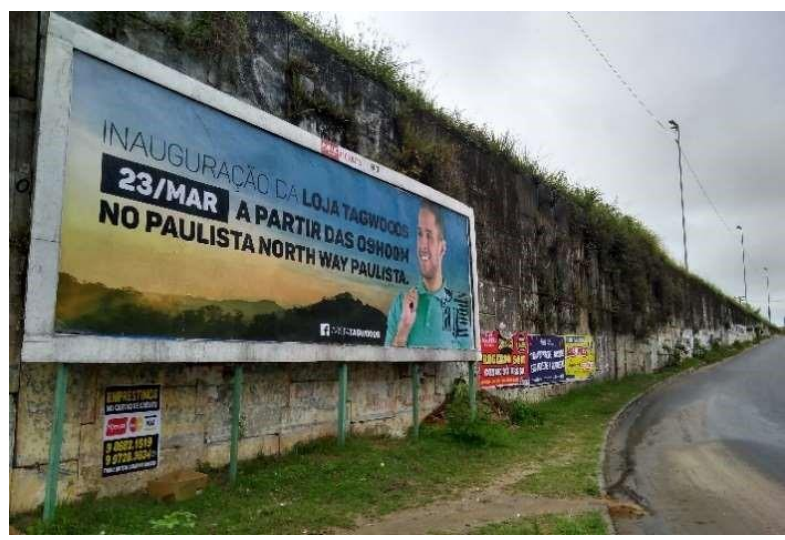

Figura 14: Contenção Leste do Viaduto Dr. Nilson Falcão. Fonte: Autor

\subsection{Principais patológicas contenções de terra armada analisadas}

A identificação das manifestações patológicas e danos estruturais foi feita por meio de observações meramente visuais, o que dificultou uma análise mais aprofundada dos problemas nos elementos prémoldados, nas armaduras e nos aterros.

A seguir são apresentados os principais problemas identificados durante as inspeções.

\subsubsection{Viaduto 1}

\section{- Arestas Danificadas}

Em alguns trechos das contenções é possível verificar que os painéis pré-fabricados estão com arestas quebradas, como na Figura 15.

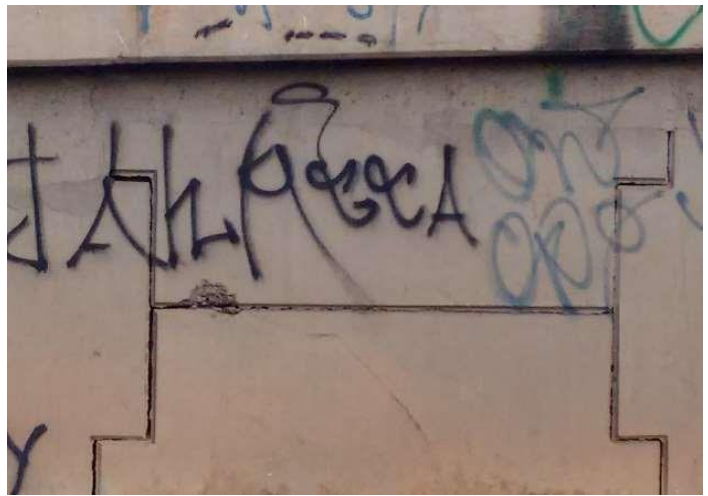

Figura 15: Escama com aresta quebrada. Fonte: Autor 


\section{- Manchas}

$\mathrm{Na}$ superfície das escamas foram observadas muitas manchas, originadas de diferentes causas (infiltração e queima de materiais).

Na Figura 16, observa-se as peças pré-moldadas com tonalidades de cores diferentes, resultado da ação da água nas suas superfícies.

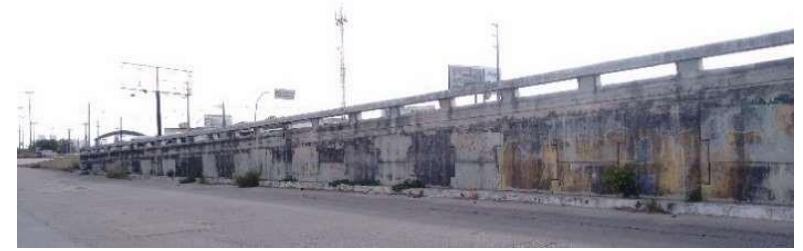

Figura 16: Manchas nas superfícies das escamas. Fonte: Autor

Também foram observadas manchas causadas pelo mau uso do viaduto. São manchas causadas pelo fogo devido a queima de materiais nas proximidades da contenção, como pode ser visto na Figura 17.

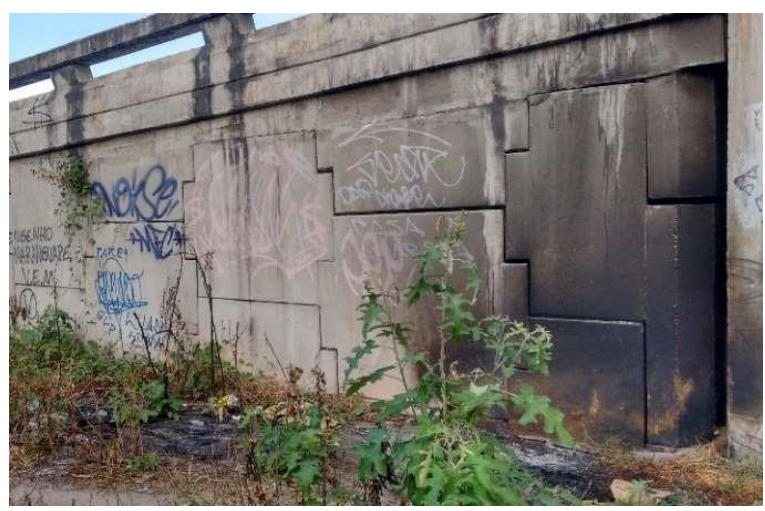

Figura 17: Manchas causadas pelo fogo. Fonte: Autor

\section{- Vegetação}

A vegetação nos espaços das juntas entre as escamas representa o problema de maior incidência e consequentemente uma das maiores causas de manifestações patológicas na estrutura de terra armada. O abandono do local também causou o crescimento da vegetação entre os dois viadutos paralelos. Tais problemas são mostrados nas Figuras 18 e 19.

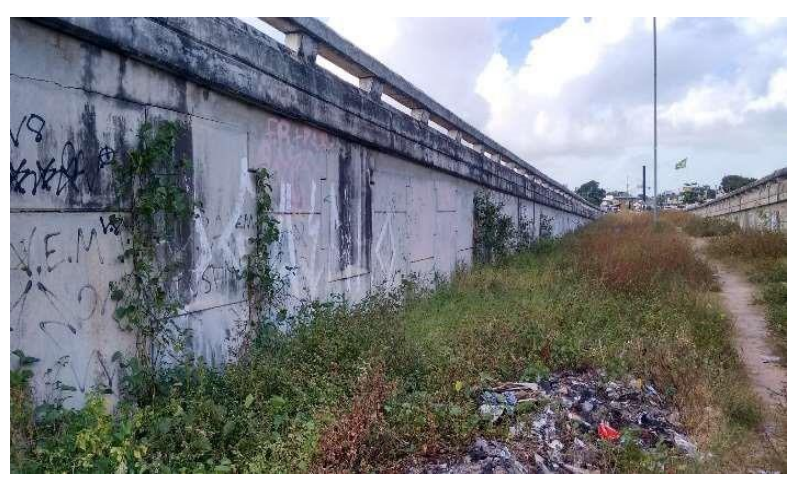

Figura 18: Vegetação entre os viadutos. Fonte: Autor

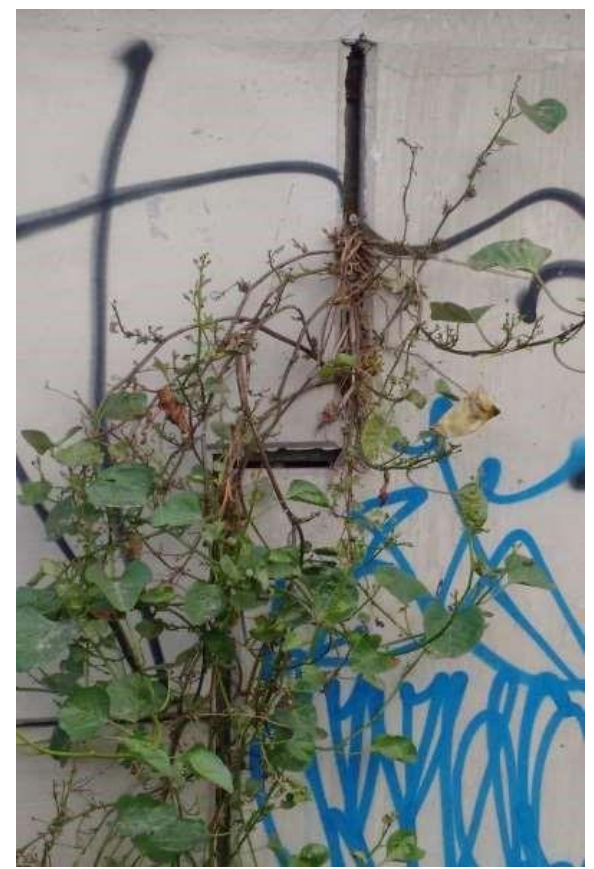

Figura 19: Presença de vegetação nas juntas das escamas. Fonte: Autor

\section{- Falhas de Construção}

Uma simples observação nesses viadutos evidencia as falhas construtivas referentes ao desaprumo das escamas. Ao longo de todo o muro é possível identificar essas falhas, como nas Figuras 20 e 21 . 


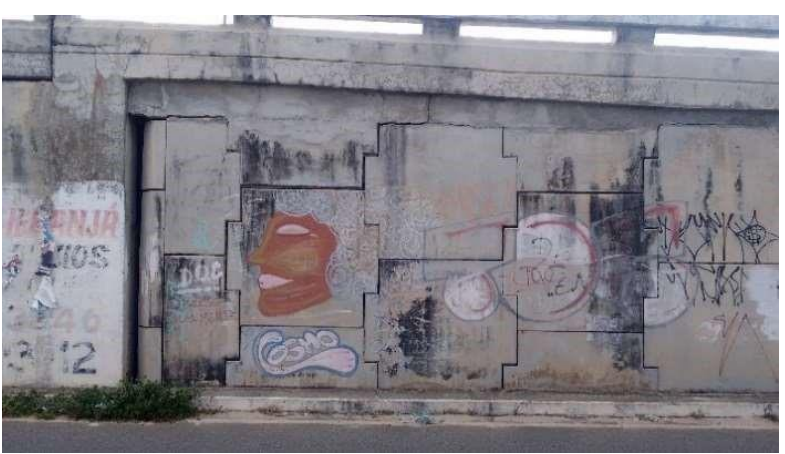

Figura 20: Desaprumo das escamas.

Fonte: Autor

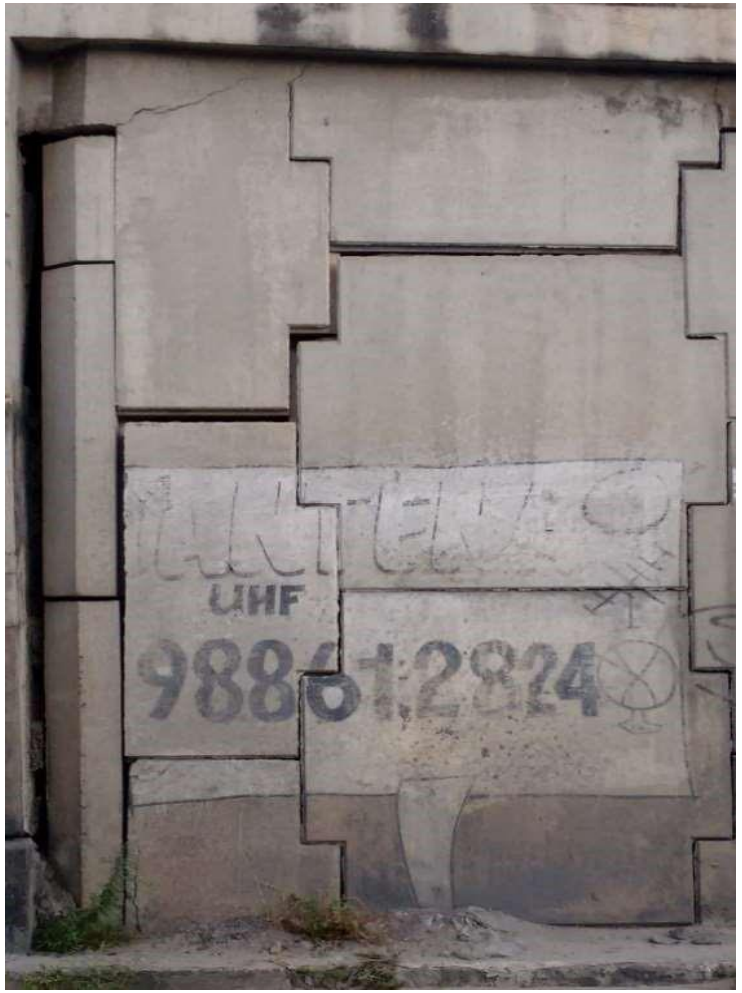

Figura 21: Detalhe de um desaprumo.

Fonte: Autor

\subsubsection{Viaduto 2}

\section{- Arestas Danificadas}

Não foram observadas quebras significativas nas escamas da contenção desses viadutos.

\section{- Manchas}

Nessas obras também foram encontradas manchas originadas pela infiltração e umidade nas placas pré-moldadas da contenção, como mostra a Figura 22.

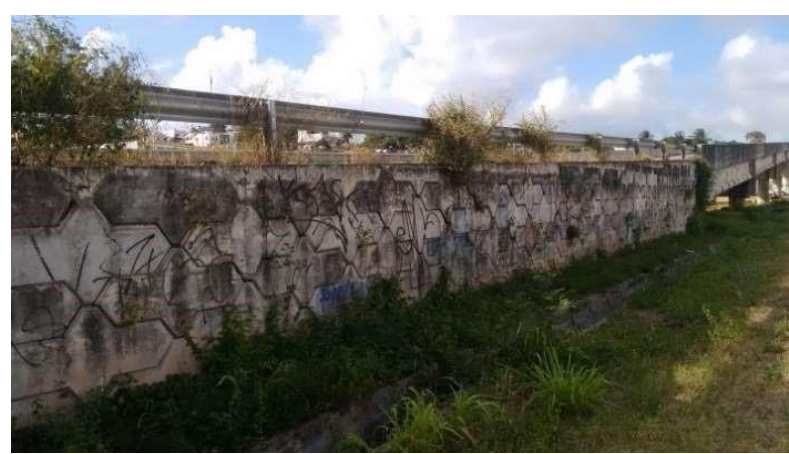

Figura 22: Manchas na contenção do viaduto Bajado. Fonte: Autor

\section{- Vegetação}

O acúmulo de terra e vegetação em algumas partes da contenção chega a cobrir todo o muro, impossibilitando a observação de outras manifestações patológicas, como comprova a Figura 23.

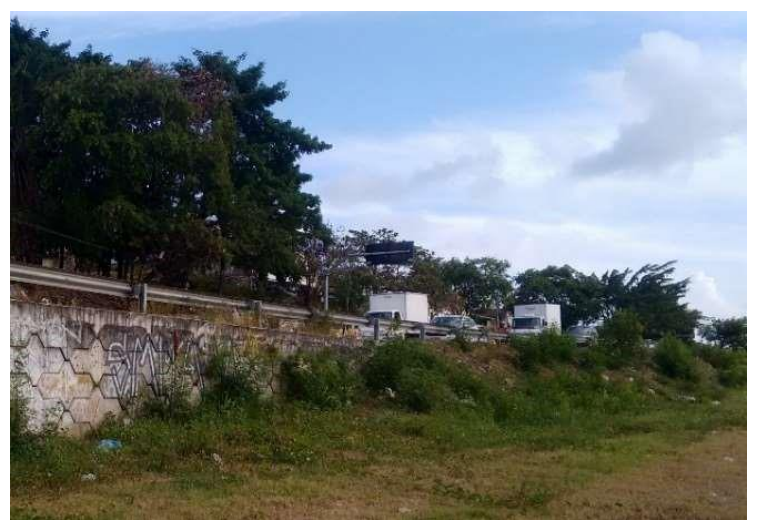

Figura 23: Acúmulo de terra próximo a parede de contenção do aterro do viaduto.

Fonte: Autor

Também é comum observar a presença de vegetação nas juntas, entre o pavimento e o muro, e na base da contenção, conforme as Figuras 24 e 25.

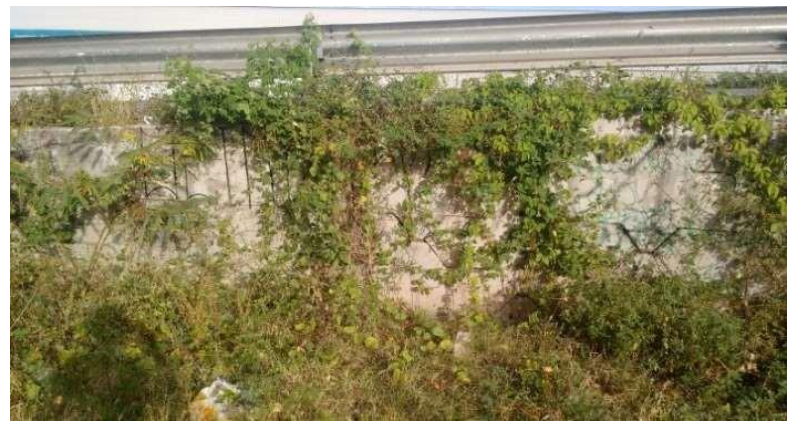

Figura 24: Vegetação cobrindo a terra armada. Fonte: Autor 


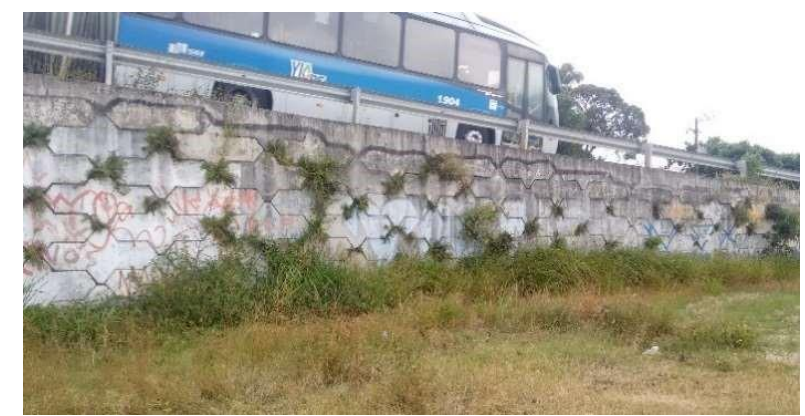

Figura 25: Vegetação nas juntas do muro. Fonte: Autor

\section{- Falhas de Construção}

Nessa obra foram identificadas diversas falhas construtivas nos elementos de concreto que compõem a terra armada. Na figura 26 , constata-se falha na ligação entre as paredes frontais e longitudinais, situação que acontece em outros trechos da contenção do viaduto.

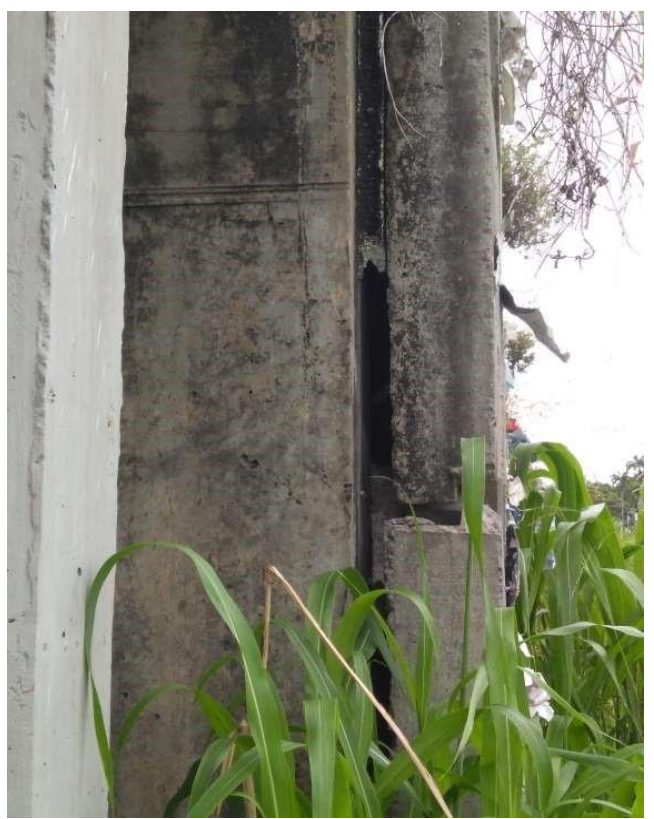

Figura 26: Falhas na ligação dos muros vertical e horizontal.

Fonte: Autor

Falhas de desaprumo dos painéis do muro também podem ser observadas, como na Figura 27.

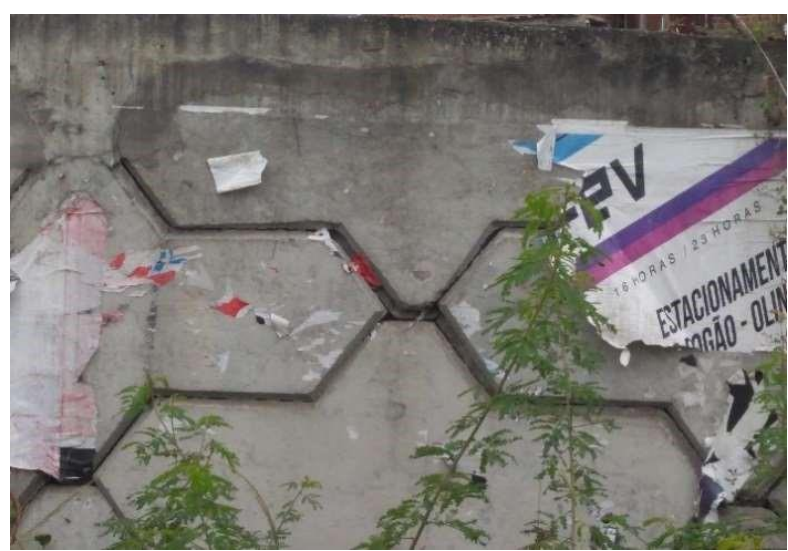

Figura 27: Desaprumo das escamas. Fonte: Autor

No encontro da superestrutura com a contenção, foi observado o desgaste do selante da junta de dilatação e a não utilização do selante na interseção do guarda-corpo de concreto e defensas metálicas, como pode ser visto na Figura 28. Tal situação influencia diretamente a infiltração de água no aterro, aumentando a incidência de manifestações patológicas nas paredes da contenção.

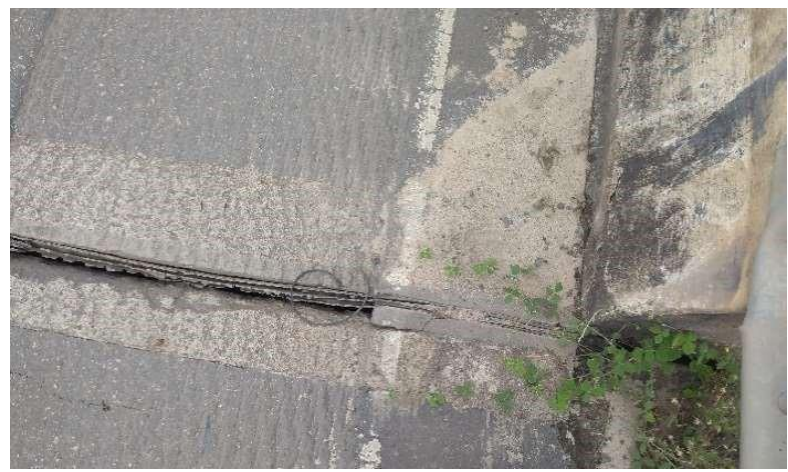

Figura 28: Desgaste da junta de dilatação (vista superior da junta entre o pavimento e o aterro).

Fonte: Autor

\subsubsection{Viaduto 3}

\section{- Arestas Danificadas}

$\mathrm{Na}$ Figura 29, são mostrados pequenos danos causados nas placas pré-moldadas do sistema de terra armada. Essas avarias são encontradas em diversas escamas, ao longo do muro. 


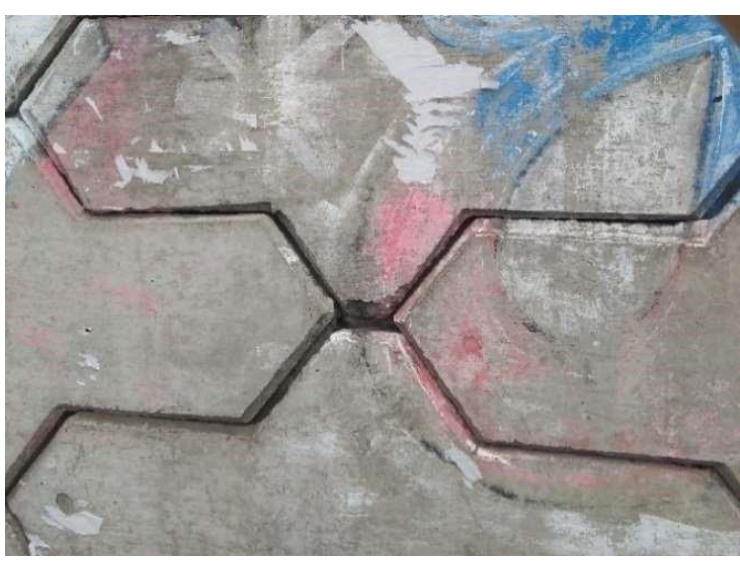

Figura 29: Arestas das escamas danificadas. Fonte: Autor

\section{- Manchas}

Foram encontradas manchas causadas por umidade na parte superior do muro de terra armada, como pôde ser visto na Figura 12.

\section{- Vegetação}

Em alguns locais, a contenção é quase totalmente encoberta pela vegetação, o que confirma o mesmo problema observado nas demais obras. Nesse caso a vegetação dificulta até o acesso ao local, como pode ser visto na Figura 30.

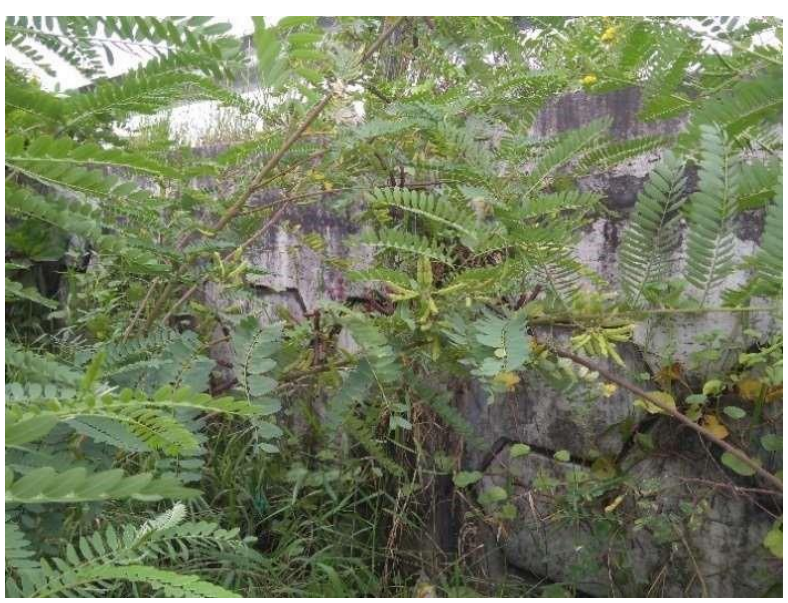

Figura 30: Vegetação no Viaduto 3.

Fonte: Autor

\section{- Falhas de Construção}

A Figura 31, ratifica o problema construtivo referente ao desaprumo das escamas, observado em diversos trechos da parede de contenção.

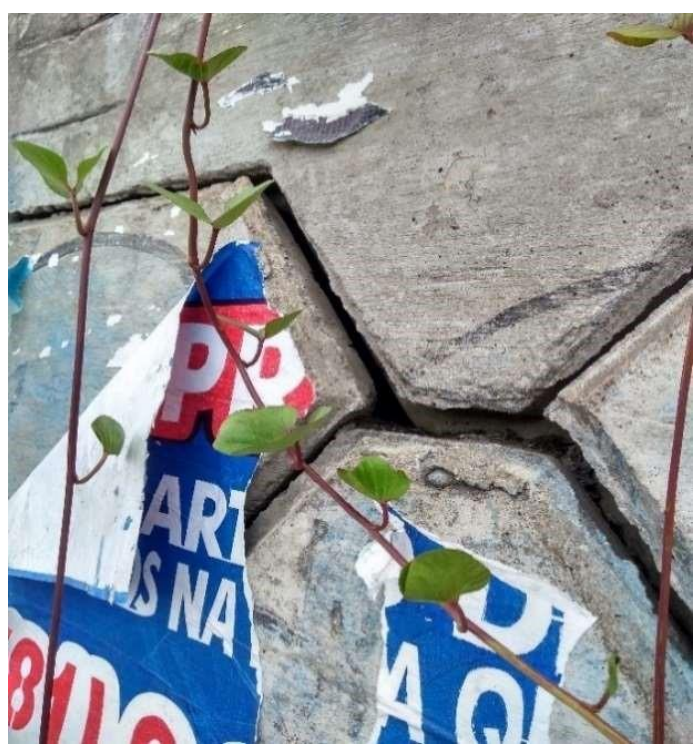

Figura 31: Desaprumo das escamas.

Fonte: Autor

Na Figura 32 é mostrado o local da interseção entre os muros frontal e longitudinal da contenção, no qual o problema do desaprumo entre as escamas é ainda mais acentuado.

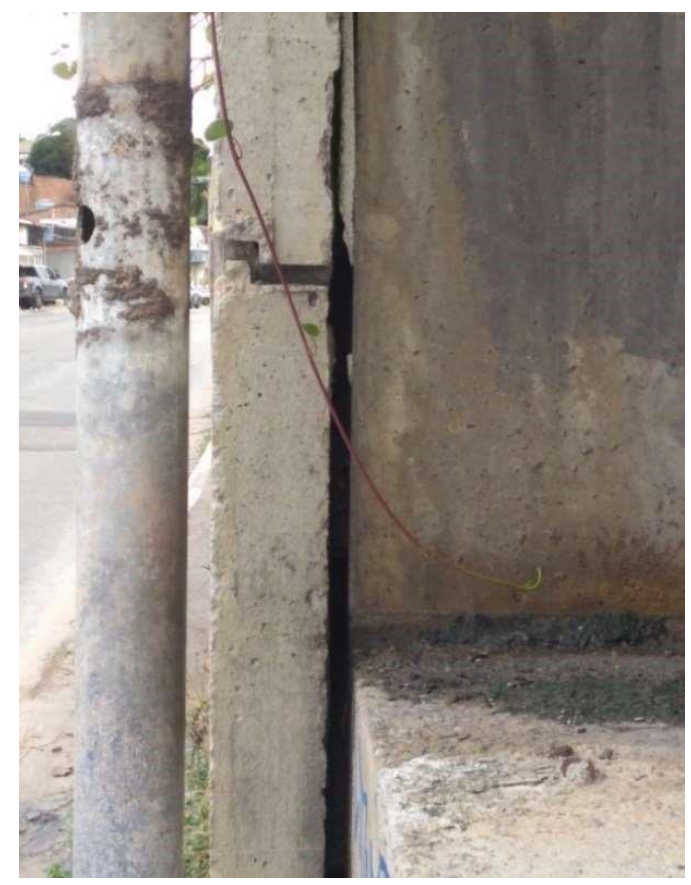

Figura 32: Grande abertura na aresta do muro. Fonte: Autor 


\subsubsection{Viaduto 4}

\section{- Arestas Danificadas}

Neste viaduto, foi observado um desgaste generalizado dos painéis pré-moldados, com grande parte das arestas danificadas, como nas Figuras 33 e 34 .

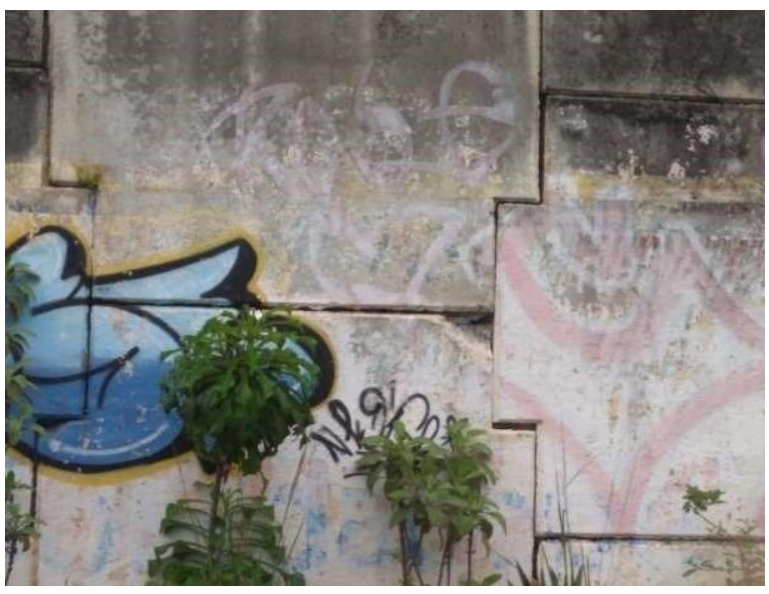

Figura 33: Aresta da escama danificada. Fonte: Autor

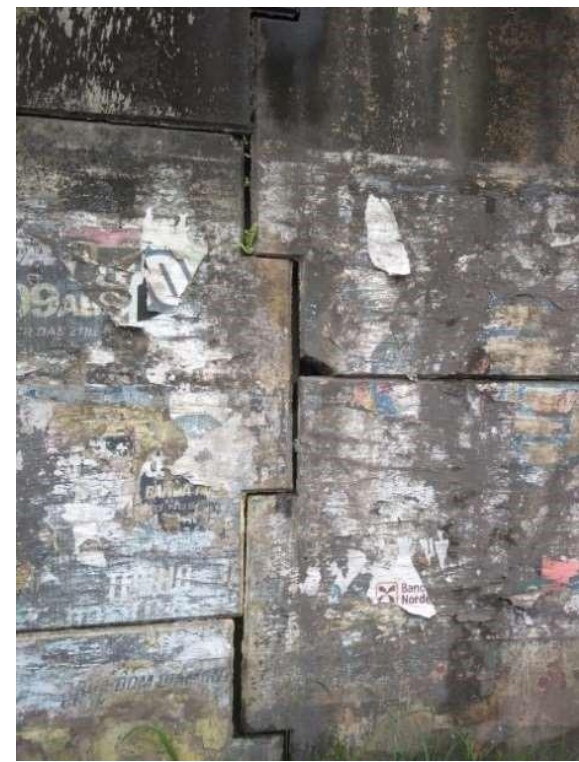

Figura 34: Outro detalhe de escama com aresta danificada.

Fonte: Autor

\section{- Manchas}

A Figura 35, mostra manchas de grande intensidade, originadas pela infiltração de água e umidade, o que leva ao surgimento de outras manifestações patológicas. Também mostra extensa vegetação ao longo das escamas.

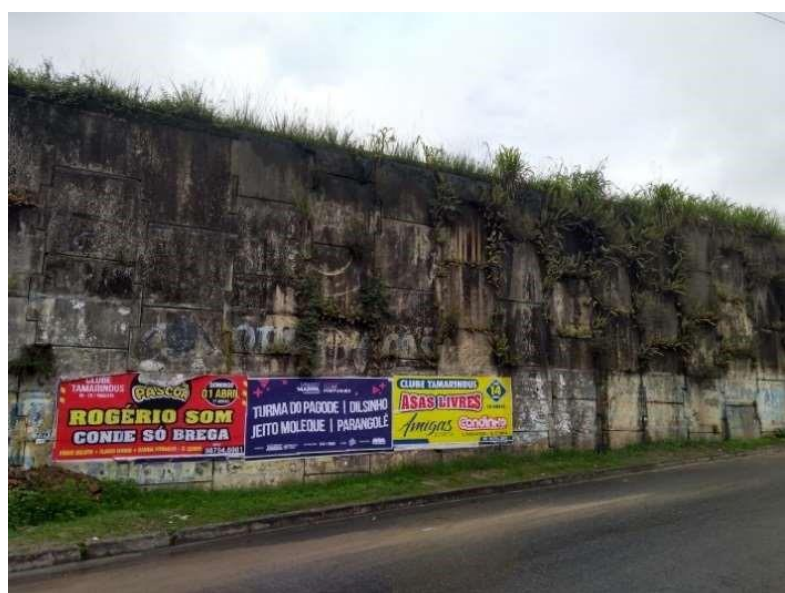

Figura 35: Manchas de grande intensidade e muita vegetação na contenção.

Fonte: Autor

\section{- Vegetação}

Das quatro obras de contenção, essa é a que se encontra no estado mais avançado de deterioração, causada principalmente pelo enraizamento $e$ proliferação de vegetação nas juntas do muro, como pode ser visto nas Figuras 35 e 36.

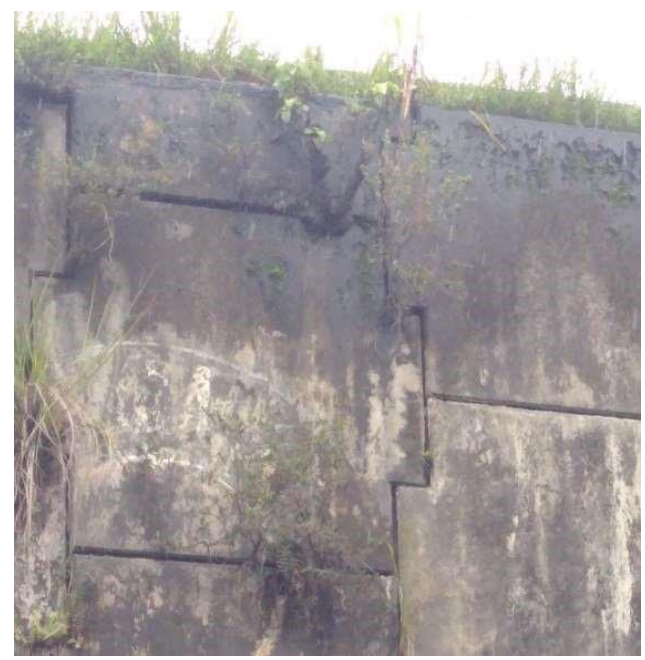

Figura 36: Vegetação enraizada entre as juntas das escamas.

Fonte: Autor

\section{- Falhas de Construção}

A Figura 37, mostra um grande desaprumo entre as escamas do muro, situação que se repete em diversos outros locais da contenção. 


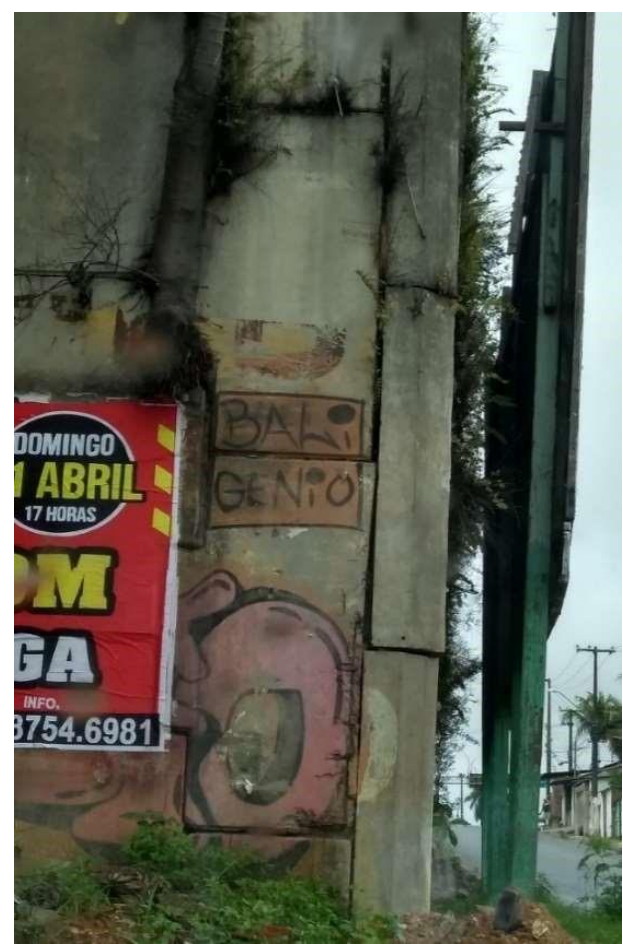

Figura 37: Desaprumo do muro de contenção. Fonte: Autor

\subsection{Considerações sobre as atuais condições de conservação das obras}

Com base nas observações feitas nas vistorias, constatou-se a ausência de manutenção em todos os viadutos, principalmente nas contenções objetos deste estudo. Constatou-se que a vegetação entre as juntas das escamas é a manifestação patológica mais facilmente encontrada, que a cada inverno vai aumentando de tamanho, provocando ainda mais danos na estrutura das contenções.

Também foi possível observar a presença de manchas causadas pelo excesso de infiltração de água nas escamas. Essa infiltração contribui para a proliferação da vegetação nas juntas, existindo casos em que o tamanho das raízes já está danificando de forma mais acentuada as placas de concreto.

A infiltração também pode está acontecendo devido a falhas na drenagem superficial, pois os dispositivos de captação da água, como calhas e drenos, não estão conduzindo-as adequadamente.
O desaprumo dos muros das contenções, que foi evidenciado em todos os viadutos, pode ter ocorrido devido à ausência de controle no nivelamento das placas, mas também pode ser proveniente do recalque diferencial da fundação, pelo fato das contenções possivelmente estarem apoiadas em solos com características e comportamentos diferentes, com a mesma fundação ao longo de toda a extensão do muro.

Os danos nos painéis pré-moldados, além de terem sido causados por falhas construtivas e ausência de manutenção, também são, em parte, resultado da ação predatória humana, como mostram as pichações, manchas de calcinação e fixações de faixas e placas de publicidade nos muros.

\section{Recomendações}

A princípio, recomenda-se que como primeira providência, seja realizada uma ação emergencial de limpeza nas paredes, com a remoção de toda a vegetação das juntas das escamas. Trata-se de serviço simples e de baixo custo, mas que melhorará bastante as condições dessas peças pré-moldadas, mitigando os problemas até que uma ação definitiva de recuperação seja realizada. A simples retirada da vegetação também possibilitará uma análise mais detalhada das reais condições das contenções visando uma solução definitiva.

Uma segunda providência seria a realização de uma análise profunda das condições de compactação dos aterros e até onde o maciço de terra pode ter sofrido alterações com as constantes infiltrações. Após a emissão de um diagnóstico conclusivo das condições gerais dos aterros e dos elementos de contenções, seria elaborado um projeto de recuperação geral.

Para minimizar essas infiltrações, recomenda-se a elaboração de projeto de drenagem para as contenções, com ênfase na drenagem superficial dos maciços.

Também se recomenda a implantação, por parte dos Órgãos responsáveis, de um sistema de gestão da manutenção das Obras de Arte Especiais, baseado nas inspeções definidas pela Norma NBR-9452/2016 - "Inspeção de pontes, viadutos e passarelas de 
concreto". Esse sistema de gestão deverá incluir as contenções dos aterros de acesso em Terra Armada.

Para implantação do sistema de gestão será necessário, primeiramente, o conhecimento de toda a documentação das obras, como projetos e memoriais utilizados para construção das contenções que ajudarão a elaborar e implementar os roteiros para as inspeções. Com base nesses dados, deverá ser feito o plano de manutenção com as atividades a serem realizadas e a periodicidade delas. É muito importante o registro dos dados obtidos nas inspeções realizadas, para que possa ser feito um acompanhamento da situação das contenções e posterior avaliação da eficiência das ações tomadas.

Também é recomendável uma melhoria estética das contenções em terra armada, transformando os imensos muros cinzas e manchados em paisagens coloridas por pinturas e painéis feitos por artistas plásticos da região. Essa mudança pode melhorar a satisfação dos moradores e usuários, ajudando a transformar esses locais em pontos de convivência.

\section{Conclusões}

Diante do que foi observado durante as inspeções, é possível concluir que os problemas encontrados nos muros de contenções analisados têm como principal causa a ausência de manutenção ao longo do tempo, resultante de uma cultura segundo a qual os recursos utilizados na conservação das obras públicas é simplesmente um gasto, e não um investimento que irá garantir uma maior durabilidade e vida útil a esses bens, construídos com os impostos pagos pela sociedade.

A situação de maior gravidade encontra-se no Viaduto 4, cujos problemas estão evoluindo há muitos anos, sem que tenham sido adotadas quaisquer providências para, pelo menos, minimizálos.

Tanto a quantidade como a intensidade das manifestações patológicas das contenções dos Viadutos 1, 2 e 3, mostram um nível de degradação muito avançado para obras com apenas cinco anos de funcionamento.

Os danos estruturais encontrados nas contenções analisadas, embora graves para esses tipos de estruturas, ainda não comprometem as suas funcionalidade e estabilidade. Porém, se não forem tomadas providências no curto prazo visando a correção dos problemas atualmente existentes, ocorrerá evidentemente, a evolução das avarias, o que implicará em elevados custos de recuperação, com prejuízos para os usuários, que enfrentarão talvez a interdição de tráfego nesses locais durante a execução das obras de correção.

Também não devem ser descartados os riscos de ocorrência de acidentes causados por rupturas das contenções e deformações dos aterros, caso os problemas existentes evoluam sem que sejam adotadas as providências cabíveis.

\section{Referências}

[1] ASSOCIAÇÃO BRASILEIRA DE NORMAS TÉCNICAS. NBR 19286: Muros em solos mecanicamente estabilizados - especificação.

Rio de Janeiro: 2016.

[2] SILVA, Nadine Henriques da. Muros de terra armada, verificação de segurança. Dissertação de Mestrado. Ramo de Estruturas e Geotecnia, Faculdade de Ciências e Tecnologias da Universidade Nova de Lisboa. Lisboa: UNL, 2012.

[3] VITÓRIO, José Afonso Pereira. Pontes rodoviárias: Fundamentos, Conservação e Gestão. Recife: CREA-PE, 2002.

[4] MAPARAGEM, Albano Sâlzon. Avaliação da interação solo-fitas metálicas e poliméricas para solução em terra armada em solos não convencionais. Dissertação de Mestrado em Ciências. Programa de pós-graduação em Geotecnia, Universidade de São Paulo. São Carlos: USP, 2011.

[5] FONTANA, Gabriela Bez; SANTOS, Adailton Antônio dos. Análise de dimensionamento de solo reforçado tipo terra armada. Artigo para Trabalho de conclusão de Curso. Graduação de Engenharia Civil, Universidade do extremo sul catarinense. Criciúma: UNESC, 2011. 
[6] SPRINGER, Fernanda Otto. Estudos de deformabilidade de escavações com solo grampeado, Dissertação de Mestrado. Ciências da Engenharia Civil: Geotecnia, Pontifícia Universidade Católica do Rio de Janeiro. Rio de Janeiro: PUC-Rio, 2001.

[7] VITÓRIO, José Afonso Pereira. Notas de aula da disciplina Reforço e Recuperação de Pontes e Viadutos. Curso de Especialização em Inspeção, Manutenção e Recuperação de Estruturas, Universidade de Pernambuco. Recife: POLI/UPE, 2017.

[8] PESSOA, R. G. Avaliação dos custos construtivos de estruturas de contenção no município de Natal/RN. Artigo para Trabalho de Conclusão de Curso. Graduação em Engenharia Civil, Universidade Federal do Rio Grande do Norte. Natal: UFRN, 2016.

[9] GENTIL, Vicente. Corrosão. 3a Edição. Rio de Janeiro: LTC Editora, 1996.

[10] THOMAZ, E. Trincas em edifícios: causas, prevenção e recuperação. São Paulo: IPT/EPUSP/PINI, 1989.

[11] SOUZA, Vicente Custódio Moreira de; RIPPER, Thomaz. Patologia, recuperação e reforço de estruturas de concreto. São Paulo: PINI, 1998. 